\title{
Complete pelvic organ prolapse associated with cervical cancer
}

\author{
Catarina Estevinho, Ana Portela Carvalho 주, Ana Rita Pinto, Fernanda Costa
}

Obstetrics and Gynaecology, Centro Hospitalar Tâmega e Sousa, Penafiel, Portugal

\section{Correspondence to} Dr Ana Portela Carvalho; ana.sofia.portela.carvalho@ gmail.com

Accepted 2 December 2020

\section{DESCRIPTION}

Pelvic organ prolapse and carcinoma of the cervix are common entities but their association is rare. In more than $60 \%$ of the cases, the uterine prolapse is present for at least 10 years. ${ }^{1}$

The displacement of the uterine cervix from the natural environment of the vagina is thought to explain a lower risk of cervical cancer due to viral infection in uterine prolapse. Nevertheless, the continuous injury of the cervical epithelium may favour the neoplastic process. ${ }^{2}$ The best treatment approach in this clinical setting is not clearly defined and vary considerably among authors. ${ }^{3}$ We present a case of a 74-year-old woman, Gesta 3 Para 3, with a 9 years history of an uterine prolapse that presented in our department. The reasons for medical visit were the onset of vaginal bleeding and increasing genital prolapse size. The patient had no prior cervical cancer screening. Physical examination revealed a complete and irreducible fourth-degree urogenital prolapse with induration of the entire vaginal mucosa, inflammatory signs and ulcerated lesions that made impossible to clearly identify the cervix (figure 1). No evidence of bladder or rectum involvement were present. Biopsies were performed and histopathology revealed squamous-cell cervical carcinoma. A pelvic MRI described a fibromatous uterus measuring $15 \times 7$, $8 \times 10 \mathrm{~cm}$, large ptosis of the uterus and bladder, bilateral parametrial invasion and hydronephrosis (figure 2). CT of the thorax and abdomen revealed no distant metastasis. She was staged according to the 2009 International Federation of Gynecology

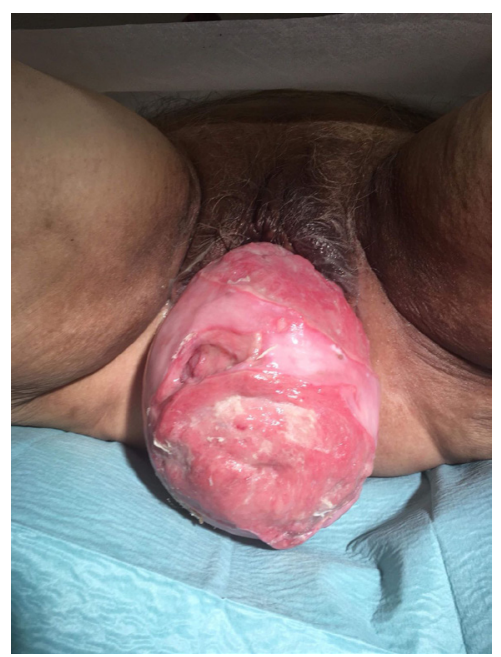

Figure 1 Complete genital prolapse and externalised cervix cancer of the case reported.

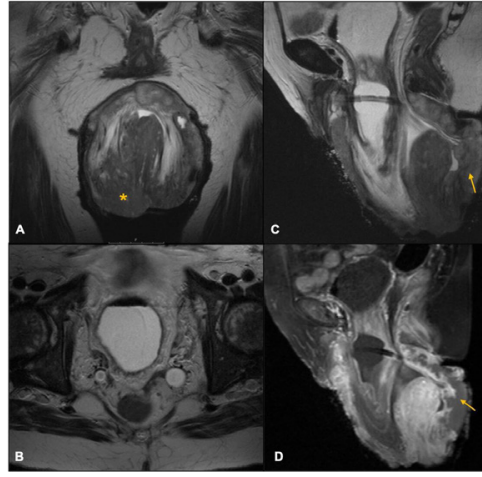

Figure 2 Coronal (A), axial (B) and sagittal (C) T2weighted images show massive anterior and middle compartment pelvic prolapse (cystocele, peritoneocele and utero-vaginal prolapse). Also note cervical tumour better depicted in the coronal plane (asterisk in A) with extensive invasion of the vagina, better seen in sagittal postcontrast images (arrows in $\mathrm{C}$ and $\mathrm{D}$ ). There is also bilateral ureteral dilatation (B) suggesting ureteric obstruction, most likely from the prolapse.

and Obstetrics staging system as at least FIGO IIIA. Radiotherapy was considered but the risk of visceral injury was high due to the volume of externalised prolapse and associated cystocele. After

\section{Patient's perspective}

People always feel embarrassed to talk openly about genital concerns. When we asked for help it was too late. We hope that our story serves as an example to highlight the importance of regular healthcare visits and to care for the elder. (Patient's daughter perspective)

\section{Learning points}

- The association between cervical cancer and uterine prolapse is rare, with few published reports in the literature.

- There is currently no consensus on the management of uterovaginal prolapse associated with carcinoma of the cervix. The optimal treatment needs to be individualised based on prognostic factors in order to improve quality of life.

- Radiotherapy is a therapeutic option for locally advanced cervical cancer. Its use might be limited in patients with uterine prolapse due to the risk of visceral injury, such as radiation cystitis. 
a multidisciplinary board meeting, given the locally advanced stage, the volume of externalised prolapse and the poor clinical status, the patient was referred to end-life care measures, regarding her comfort. The patient underwent rapid deterioration of her general condition manifested by increasing asthenia, cachexia, nausea and vomiting episodes. One month after the initial presentation, the patient died.

Contributors CE made the decision to report and collected the data and images. CE and APC interpreted the data and wrote the manuscript. ARP and FC examined and treated the patient. All authors made a significant contribution to this paper and have revised and approved the final version of the manuscript.

Funding The authors have not declared a specific grant for this research from any funding agency in the public, commercial or not-for-profit sectors.
Competing interests None declared.

Patient consent for publication Not required.

Provenance and peer review Not commissioned; externally peer reviewed.

\section{ORCID iD}

Ana Portela Carvalho http://orcid.org/0000-0002-1311-7035

\section{REFERENCES}

1 Rocker I. Malignant changes in procidentia. The Incidence During the Years 194954 at Addenbrooke's Hospital, Cambridge. BJOG:An international journal of O\&G 1958;65:89-91.

2 Tindall VR. Jeffcoate's Principles of Gynecology. 600. 5th edn. Oxford: Butterworth and Heinemann, 1987.

3 Loizzi V, Cormio G, Selvaggi L, et al. Locally advanced cervical cancer associated with complete uterine prolapse. Eur J Cancer Care 2010;19:548-50.

Copyright 2021 BMJ Publishing Group. All rights reserved. For permission to reuse any of this content visit

https://www.bmj.com/company/products-services/rights-and-licensing/permissions/

BMJ Case Report Fellows may re-use this article for personal use and teaching without any further permission.

Become a Fellow of BMJ Case Reports today and you can:

- Submit as many cases as you like

- Enjoy fast sympathetic peer review and rapid publication of accepted articles

- Access all the published articles

Re-use any of the published material for personal use and teaching without further permission

\section{Customer Service}

If you have any further queries about your subscription, please contact our customer services team on +44 (0) 2071111105 or via email at support@bmj.com.

Visit casereports.bmj.com for more articles like this and to become a Fellow 